\title{
Pediatri Ünitelerinde Aile Merkezli Bakım ile Ebeveynlere Sağlanan Destek Düzeyi Arasındaki Ilişki
}

\author{
(1D) Hilal Yılmaz ${ }^{1}$, (D) Aysel Kökcü Doğan² \\ ${ }^{1}$ Uzm. Hemşire, İstanbul Medipol Üniversitesi, İstanbul, Türkiye \\ ${ }^{2}$ Dr. Öğr. Üyesi, İstanbul Medipol Üniversitesi Hemşirelik Bölümü, İstanbul, Türkiye \\ Öz
}

\section{Pediatri Ünitelerinde Aile Merkezli Bakım ile Ebeveynlere Sağlanan Destek Düzeyi Arasındaki ilișki}

Amaç: Bu çalışmada, pediatri ünitelerinde yatan çocuklara verilen aile merkezli bakım ile ebeveynlere sağlanan destek düzeyi arasındaki ilişkiyi belirlemek amaçlanmıştır.

Yöntem: Veri toplama aracı olarak "Aile Merkezli Bakım Ölçeği” ve "Ebeveyn Destek Ölçeği” kullanıldı. Araştırmanın örneklemini, İstanbul'da bulunan özel bir vakıf üniversitesi hastanesinin pediatri ünitelerine müracaat eden, üç gün ve üzeri yatış yapmış tüm çocukların araștırmaya katılmaya gönüllü 155 ebeveyni olușturdu.

Bulgular: Araștırmaya katılan ebeveynlerin \%80'i kadındı. Araștırma kapsamında "Aile Merkezli Bakım Ölçeği” "eșleșme yüzdesi" puan

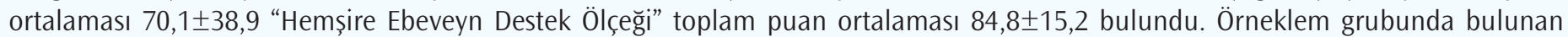
ebeveynlerin eğitim düzeyi, çalışma durumu, çocuğunun hastanede kalış süresi ve çocuğunun yattığı ünite ile her iki ölçek arasında istatistiksel olarak anlamlı farklılık tespit edildi $(p<0,05)$.

Sonuç: Aile merkezli bakım uygulamaları ile ilgili hemşirelerin ebeveynlere ve çocuklara verdikleri bakımdan memnun oldukları, ebeveynlere sağlanan destek düzeyi arttıkça ebeveynlerin aile merkezli bakıma katılımının da arttığı belirlendi. Bu sonuçlar doğrultusunda hemşireler aile merkezli bakımda ebeveynlerin rolünü kabul etmeli ve ebeveynlere gereksinimleri doğrultusunda destek vermelidir.

Anahtar Kelimeler: Aile Merkezli Bakım, Destek, Ebeveyn, Hemşire

\section{Abstract}

Relationship Between Family-Centered Care in Pediatric Units and The Level of Support Provided to Parents

Objective: This descriptive study was carried out in order to determine the relationship between family-centered care given to children in pediatric units and the level of support provided to parents.

Methods: "Family-Centered Care Scale" and "Parental Support Scale" were used as data collection tools in the study. The sample of the study consisted of 155 voluntary parents of all children who applied to the pediatric units of a private foundation university hospital in Istanbul and had hospitalized for three days or more, volunteering to participate.

Results: $80 \%$ of the parents participating in the study were women. Within the scope of the study, the average point of "Matching Percentage" in the "Family Centered Care Scale" was found to be $70.1 \pm 38.9$ and the total score average of the "Nurse Parent Support Scale" was $84.8 \pm 15.2$. Statistically significant difference was found between the educational level of parents in sample group, parents' employment status, length of stay in the hospital, and the unit where child was hospitalized $(p<0,05)$.

Conclusion: It was determined that the nurses related to family-centered care practices were satisfied with the care they gave to parents and children, and as the level of support provided to parents increased, parental participation in family-centered care increased. In line with these results, nurses should accept the role of parents in family-centered care and support parents in line with their needs. Keywords: Family-Centered Care, Support, Parent, Nurse

Nasıl Atıf Yapmalı / How to Cite: Yılmaz H, Doğan AK. Pediatri Ünitelerinde Aile Merkezli Bakım ile Ebeveynlere Sağlanan Destek Düzeyi Arasındaki Ilișki. MKÜ Tip Dergisi. 2021;12(43):119-130. https://doi.org/10.17944/mkutfd.872386 


\section{Giris}

Aile Merkezli Bakımda amaç; aileyle iș birliği yapmak, çocuk ve aile hakkında bilgi almak, çocuk ile ailenin hastalığı ve hastaneye yatmasında yașadıkları anksiyeteyi en aza indirip, çocuğun zihinsel, fiziksel, psikolojik potansiyelini en üst seviyeye çıkarmak ve hastanede kalış süresini en aza indirmektir (1). Ailelerin hastanede çocuklarının bakımına dahil edilmeleri için bulundukları ortamı tanıması ve hemşireler ile aralarında etkili bir iletișim olması gerekir. Bunun içinde çocuğun kliniğe kabulü ile; aile ve çocuklara kliniğin tanıtılması, klinik rutinleri, çalıșanlar hakkında bilgi verilmesi ve çocuğun yatıșından itibaren tedavi süresince çocuk ile ilgili bilgilerin eksiksiz ve tarafsız aile ile paylașılması, Aile Merkezli Bakım ile ilișkili önemli hemşirelik uygulamalarıdır (2).

Konu ile ilgili literatür tarandığında özellikle İngiltere, Kanada, Amerika Birleșik Devletleri gibi gelişmiş ülkelerin çocuk hastanelerinde ebeveyn ve çocuğuna Aile Merkezli Bakım ilkeleri doğrultusunda bakım verildiği ve Aile Merkezli Bakımın hastanelerin kurum politikası olarak kabul edilip uygulandığı görülmektedir (3). Aile Merkezli Bakımın ülkemizdeki durumu incelendiğinde, ebeveynlerin çocuğu ile birlikte hastane ortamında kalmalarına ilișkin standart uygulama prosedürünün olmadığı ve hastanelerdeki uygulamalarda farklılıkların olduğu görülmektedir (4).

Çocuğu hastanede yatan ebeveynlere destek olma hemşirelik bakımının önemli bir yönü olarak görülmektedir. Hemşire-ebeveyn desteği; hastanede yatan çocukların ebeveynlerini destekleyici, etkin iletișim ile sürekli bilgi sağlama ve ebeveyni bakıma dahil ederek stresini azaltmasına yardımcı olmak olarak tanımlanır. Ebeveynlerin olumlu geri bildirim ve değerlendirme yoluyla ebeveynlik rolünü sürdürmelerine destek olur; duygusal destek ve kaliteli hemşirelik bakımı sağlar. Hemşirelerin destekleyici davranıșları; dinleme ve empati kurma, bilgi verme ve açıklamalar yapma, çocuğun bakımına katılımda teșvik etme ve güven verme, doğrulama, ilgi ve değer verme, bütünlüğü koruma, önerilerde bulunma ve mevcut sorunları çözme şeklinde sıralanabilir (5).

Bu çalıșmada Pediatri ünitelerinde verilen aile merkezli bakım ile ebeveynlere sağlanan destek düzeyi arasındaki ilişkinin belirlenmesi amaçlanmıștır.

\section{GEREÇ VE YÖNTEM}

Araștırmada örneklem seçimine gidilmemiş olup İstanbul'da bulunan özel bir vakıf üniversitesi hastanesinin pediatri ünitelerinde en az 3 gün süre ile çocukları yatan araştırmaya katılmaya gönüllü 124 anne ve 31 baba olmak üzere toplam 155 ebeveyn örneklem grubunu olușturmuștur.

\section{Örneklem}

Araștırmada "Aile Merkezli Bakım Ölçeği" ve "Hemşire Ebeveyn Destek Ölçeği” kullanılarak veriler toplanmıştır. Ebe- veynlere araștırmaya bașlamadan önce araștırmanın amacı ve ölçekler hakkında gerekli açıklamalar yapıldıktan sonra onamları alınmıștır. Verilerin toplanması için ebeveynlere ortalama 20 dakikalık süre ayrılmıștır.

\section{Veri Toplama Tekniği}

Araștırmada "Aile Merkezli Bakım Ölçeği" ve "Hemșire Ebeveyn Destek Ölçeği” kullanılarak veriler toplanmıștır. Ebeveynlere araștırmaya bașlamadan önce araștırmanın amacı ve ölçekler hakkında gerekli açıklamalar yapıldıktan sonra onamları alınmıştır. Verilerin toplanması için ebeveynlere ortalama 20 dakikalık süre ayrılmıștır.

\section{Aile Merkezli Bakım Ölçeği (AMBÖ)}

Curley ve ark. tarafından 2013 yılında geliștirilen ve Altıparmak, Taş Arslan tarafından 2015 yılında Türkçeye uyarlanan ölçek ebeveynlerin hastanede kaldıkları süre içerisinde verilen hemșirelik bakımının değerlendirilmesi ile ilgili soruları önem ve tutarlılık açısından değerlendirmektedir. Ölçek 7 madde ve iki bölümden oluşmaktadır. Her madde (1) hiç memnun değilim, (5) çok memnunum olarak puanlanan beșli likert tipinde ölçektir. Toplam puan hem önemlilik hem tutarlılık bölümleri için 7-35 arasındadır ve ölçekte alt boyutlar bulunmamaktadır. Önemlilik bölümünde hemșireler ile ilgili verilen maddelerin ebeveynler için ne kadar önemli olduğu, tutarlılık bölümünde ise; hemşirelerin verilen maddeleri ne kadar tutarlı yaptığı ölçülmüștür (19). Puan değerlendirilmesinde önemlilik ve tutarlılık puanları tek bir puanda birleștirilmektedir ve bu puan eșleșme yüzdesini ifade eder. Eșleșme yüzdesinin artması hemșirelerin ebeveynler ile ilgilendiği ve çocuğa iyi bakım verildiğini ifade eder. Aile Merkezli Bakım Ölçeği” Cronbach Alfa değeri önemlilik bölümü 0,70 tutarlılık bölümü 0,79 olarak belirlenmiștir. Bu çalıșmada ise önemlilik bölümü için Cronbach alfa değeri 0,86 tutarlılık bölümü için Cronbach alfa değeri 0,85 olarak bulundu.

\section{Hemșire Ebeveyn Destek Ölçeği (HEDÖ)}

Miles, Carlson, Brunssen tarafından 1999 yılında geliștirilen, Yiğit ve ark. tarafından 2015 yılında Türkçeye uyarlanan ölçek hemşirelerin ebeveyn desteklerini ölçmek amacı ile kullanılmaktadır. Ölçek, (1) hemen hemen hiç, (2) ara sıra, (3) bazen, (4) çoğu zaman ve (5) her zaman şeklinde beșli likert tipinde, 21 maddeden ve dört alt boyuttan olușmaktadır. "Bilgi verme ve Illetișim Desteği” (9 madde), "Duygusal Destek” (3 madde), "Saygı Desteği" (4 madde), "Kaliteli Bakım Verme" (5 madde) alt boyutlardır (50). Ölçekten alınabilecek en düşük puan 21, en yüksek puan 105’tir. "Hemșire Ebeveyn Destek Ölçeği” Cronbach Alfa değeri 0,87'dir. Bu çalıșmada ise Cronbach alfa değeri 0,86 bulunmuștur. Puan arttıkça hemşirelerin ebeveynlere gösterdiği destek düzeyi artar. 


\section{İstatistiksel Analiz}

Araştırmada elde edilen veriler SPSS (Statistical Package for Social Sciences) for Windows 22.0 programı kullanılarak analiz edildi. Verilerin değerlendirilmesinde tanımlayıc istatistiksel yöntemleri olarak sayı, yüzde, ortalama, standart sapma kullanıldı. İki bağımsız grup arasında niceliksel sürekli verilerin karşılaștırılmasında t-testi, ikiden fazla bağımsız grup arasında niceliksel sürekli verilerin karșılaștırılmasında Tek yönlü (One way) Anova testi kullanıldı. Anova testi sonrasında farklılıkları belirlemek üzere tamamlayıc post-hoc analizi olarak Scheffe testi kullanıldı. Araştırmanın sürekli değişkenleri arasında pearson korelasyon analizi uygulandı. Tüm istatistiksel analiz için, p değeri <0,05 anlamlı kabul edildi.

\section{BULGULAR}

Örneklem grubunda yer alan ebeveynlerin \%80'inin $(n=154)$ kadın, \%54,2'sinin 31-40 yaș aralığında ( $n=84)$, \%35,5’inin üniversite mezunu olduğu $(n=55), \% 61,7$ 'sinin herhangi bir iște çalıșmadığı $(n=104), \% 82,6$ 'sının SGK'na bağlı sağlık güvencesinin olduğu ( $n=128), \% 61,3$ 'ünün ekonomik durumunun orta ve altı olduğu $(n=95)$ tespit edildi. Ebeveynlerin \%41,9'unun 2 çocuğu olduğu ( $n=65)$, \%52,9'unun erkek çocuğu olduğu ( $n=82), \% 24,5$ ’inin 6-12 yaș aralığında çocuğunun olduğu ( $n=38), \% 33$, 5 ’inin çocuğunun otuz gün ve üzeri hastanede yatıș yaptığı $(n=52), \% 49$,7'unun çocuğunun Pediatri KiT ünitesinde yattığı ( $n=77), \% 51,6$ 'sının çocuğunun daha önce hastanede yatıș öyküsünün olduğu $(n=80)$ tespit edildi (Tablo 1).

Araștırmaya katılan ebeveynlerin "Aile Merkezli Bakım Eș-

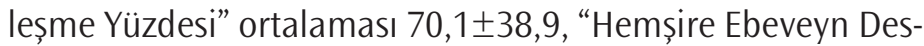
tek Ölçeği” toplam puan ortalaması 84,8 $\pm 15,2$ olarak tespit edildi (Tablo 2).

Araștırmada kullanılan Aile Merkezli Bakım Ölçeği ile Hemşire Ebeveyn Destek Ölçeği ve tüm alt boyutlarda (Aile Merkezli Bakım Ölçeği Eșleșme Yüzdesi ile Önemlilik hariç) anlamlı ilișki tespit edildi $(p<0,05)$ (Tablo 3).

Aile Merkezli Bakım Ölçeği Tutarlılık bölümü puanları ile ebeveynlerin cinsiyet, eğitim düzeyi, çalıșma durumları, çocuklarının yașı, çocuklarının hastanede kalış süresi, çocuklarının hastanede yattığı ünite ve çocuklarının hastanede yatış öyküsü arasında anlamlı farklılık tespit edildi $(p<0,05)$ (Tablo 4).

Örneklem grubunda yer alan kadın ebeveynlerin $(31,2 \pm 4)$, eğitim düzeyi ilkokul olanların $(33,1 \pm 3,6)$ çalıșmayanların

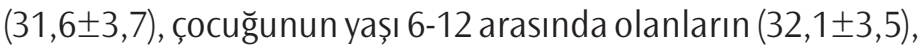
çocuğunun hastanede kalıș süresi onaltı-otuz gün olanların $(32,2 \pm 3,7)$, çocuğunun yattığı ünite pediatri KiT olanların $(32,2 \pm 3,4)$, çocuğunun daha önceden hastanede yatış öyküsü olanların $(31,5 \pm 4,3)$ aile merkezli bakım tutarlılık puanları diğer gruplardan daha yüksek belirlendi (Tablo 4).

\section{Tablo 1. Tanitıc Özellikler (N=155)}

\begin{tabular}{|c|c|c|c|}
\hline & Gruplar & Frekans(n) & Yüzde (\%) \\
\hline \multirow{2}{*}{ Cinsiyet } & Kadın & 124 & 80,0 \\
\hline & Erkek & 31 & 20,0 \\
\hline \multirow{3}{*}{ Yaş } & 30 ve Altı & 42 & 27,1 \\
\hline & $31-40$ & 84 & 54,2 \\
\hline & 40 Üzeri & 29 & 18,7 \\
\hline \multirow{4}{*}{ Eğitim Düzeyi } & Illkokul & 35 & 22,6 \\
\hline & Ortaokul & 26 & 16,8 \\
\hline & Lise & 39 & 25,2 \\
\hline & Üniversite & 55 & 35,5 \\
\hline \multirow{2}{*}{ Çalışma Durumu } & Evet & 51 & 32,9 \\
\hline & Hayır & 104 & 67,1 \\
\hline \multirow{4}{*}{ Sağ|ık Güvencesi } & Sgk & 128 & 82,6 \\
\hline & Yeșil Kart & 4 & 2,6 \\
\hline & $\begin{array}{l}\text { Özel Sağlık } \\
\text { Sigortası }\end{array}$ & 10 & 6,5 \\
\hline & Yok & 13 & 8,4 \\
\hline \multirow{3}{*}{$\begin{array}{l}\text { Ekonomik } \\
\text { Durumu }\end{array}$} & Çok Iyi & 10 & 6,5 \\
\hline & İyi & 50 & 32,3 \\
\hline & Orta ve Altı & 95 & 61,3 \\
\hline \multirow{4}{*}{ Çocuk Sayısı } & 1 & 45 & 29,0 \\
\hline & 2 & 65 & 41,9 \\
\hline & 3 & 29 & 18,7 \\
\hline & 4 ve Üzeri & 16 & 10,3 \\
\hline \multirow{2}{*}{$\begin{array}{l}\text { Çocuğun } \\
\text { Cinsiyeti }\end{array}$} & KIZ & 73 & 47,1 \\
\hline & Erkek & 82 & 52,9 \\
\hline \multirow{5}{*}{ Çocuğun Yașı } & Sifir-bir & 28 & 18,1 \\
\hline & Bir-üç & 33 & 21,3 \\
\hline & Üç-altı & 30 & 19,4 \\
\hline & Altı-oniki & 38 & 24,5 \\
\hline & 0niki-onsekiz & 26 & 16,8 \\
\hline \multirow{4}{*}{$\begin{array}{l}\text { Çocuğun Kalıș } \\
\text { Süresi }\end{array}$} & Üç-yedi & 50 & 32,3 \\
\hline & Sekiz-onbes & 25 & 16,1 \\
\hline & Onalti-otuz & 28 & 18,1 \\
\hline & 0tuz Üzeri & 52 & 33,5 \\
\hline \multirow{4}{*}{$\begin{array}{l}\text { Çocuğun Yattığı } \\
\text { Ünite }\end{array}$} & Pediatri Servisi & 52 & 33,5 \\
\hline & Pediatri Kit & 77 & 49,7 \\
\hline & $\mathrm{PICU}$ & 6 & 3,9 \\
\hline & $\mathrm{NICU}$ & 20 & 12,9 \\
\hline \multirow{2}{*}{ Yatış Öyküsü } & Evet & 80 & 51,6 \\
\hline & Hayır & 75 & 48,4 \\
\hline
\end{tabular}


Araștırmaya katılan ebeveynlerin Eșleșme Yüzdesi puanları ile eğitim düzeyi, çalıșma durumu, çocuğunun hastanede kalıș süresi ve çocuğunun yattığı ünite arasında istatistiksel olarak anlamlı farklılık tespit edildi (Tablo 4).

Eğitim düzeyi ilkokul olan ebeveynlerin $(89,7 \pm 24,8)$, ça-

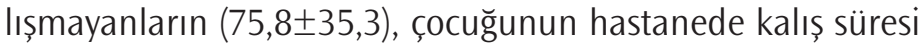
otuz gün üzeri olanların $(84,1 \pm 27,8)$, çocuğunun yattığı ünite pediatri KiT olanların $(82,7 \pm 29,2)$ eșleșme yüzdesi puanlarının diğer gruplara göre daha yüksek olduğu belirlendi (Tablo 4).

\begin{tabular}{|c|c|c|c|c|}
\hline & $0 \mathrm{rt} \pm$ & SS & Min. & Max. \\
\hline $\begin{array}{l}\text { Aile } \\
\text { Merkezli } \\
\text { Bakım } \\
\text { Önemlilik }\end{array}$ & $32,684 \pm$ & 2,940 & 25,000 & 35,000 \\
\hline $\begin{array}{l}\text { Aile } \\
\text { Merkezli } \\
\text { Bakım } \\
\text { Tutarlılık }\end{array}$ & $30,626 \pm$ & 4,768 & 14,000 & 35,000 \\
\hline $\begin{array}{l}\text { Eșleșme } \\
\text { Yüzdesi }\end{array}$ & $70,138 \pm$ & 38,949 & 0,000 & 100,000 \\
\hline $\begin{array}{l}\text { Bilgi Verme } \\
\text { ve İletișim } \\
\text { Desteği }\end{array}$ & $36,781 \pm$ & 6,662 & 19,000 & 45,000 \\
\hline $\begin{array}{l}\text { Duygusal } \\
\text { Destek }\end{array}$ & $11,845 \pm$ & 2,817 & 4,000 & 15,000 \\
\hline $\begin{array}{l}\text { Saygı } \\
\text { Desteği }\end{array}$ & $16,548 \pm$ & 3,234 & 8,000 & 20,000 \\
\hline $\begin{array}{l}\text { Kaliteli } \\
\text { Bakım } \\
\text { Verme }\end{array}$ & $19,697 \pm$ & 3,772 & 10,000 & 25,000 \\
\hline $\begin{array}{l}\text { Hemșire } \\
\text { Ebeveyn } \\
\text { Destek } \\
\text { Toplam }\end{array}$ & $84,871 \pm$ & 15,208 & 45,000 & 105,000 \\
\hline
\end{tabular}

Araștırmaya katılan ebeveynlerin HEDÖ Bilgi Verme ve İletişim Desteği Alt Boyut Puanları ile cinsiyet, eğitim düzeyi, çalışma durumu, çocuğun yaşı, çocuğunun hastanede kalış süresi, çocuğunun yattığı ünite ve yatış öyküsü arasında istatistiksel olarak anlamlı farklılık tespit edildi (Tablo 5).

Kadın ebeveynlerin $(37,4 \pm 6,5)$, eğitim düzeyi ilkokul olanların $(35,6 \pm 7,1)$, çalıșmayanların $(38,1 \pm 6,4)$, çocuğunun yașı 6-12 olanların (38,8 $\pm 5,7)$, çocuğunun hastanede kalıș süresi onaltı-otuz gün olanların $(37,8 \pm 6,1)$, çocuğunun yattığı ünite
Pediatri KIT olanların $(39,1 \pm 5,8)$, çocuğunun hastaneye yatış öyküsü olanların $(37,3 \pm 6,6)$ puan ortalamaları diğer gruplardan en yüksekti (Tablo 5).

Örneklem grubunda bulunan ebeveynlerin HEDÖ Duygusal Destek alt boyut puanları ile cinsiyet, eğitim düzeyi, çalışma durumu, çocuğun yașı, çocuğunun hastanede kalış süresi, çocuğunun yattığı ünite ve yatış öyküsü arasında istatistiksel olarak anlamlı farklılık tespit edildi ( $<<0,05)$ (Tablo 5).

Araștırmaya dahil olan kadın ebeveynlerin $(12,2 \pm 2,5)$, eğitim düzeyi ilkokul olanların $(13,4 \pm 2,172)$, çalıșmayanların $(12,442 \pm 2,6)$, çocuğunun yașı 6-12 olanların $(12,3 \pm 2,5)$, çocuğunun hastanede kalıs süresi on altı-otuz gün olanların $(12,3 \pm 2,3)$, çocuğun yattığı ünite pediatri KiT olanların $(12,8 \pm 2,1)$, çocuğunun hastanede yatış öyküsü olan ebeveynlerin $(12,4 \pm 2,4)$ duygusal destek alt boyut puanları diğer gruplara göre daha yüksek idi (Tablo 5).

Araștırmaya katılan ebeveynlerin HEDÖ Saygı Desteği alt boyut puanları ile cinsiyet, eğitim düzeyi, çalıșma durumu, ekonomik durum, çocuğunun hastanede kalış süresi, çocuğunun yattığı ünite ve yatış öyküsü arasında istatistiksel olarak anlamlı farklılık tespit edildi ( $p<0,05)$, (Tablo 5).

Kadın ebeveynlerin $(17,1 \pm 2,9)$, eğitim düzeyi ilkokul olanların (18,4 $\pm 2,5)$, çalıșmayanların $(17,3 \pm 2,8)$, ekonomik durumu orta ve altı olanların $(17,1 \pm 3,1)$, çocuğunun hastanede kalış süresi onaltı-otuz gün olanların $(17,2 \pm 2,7)$, çocuğunun yattı̆̆ı ünite pediatri KiT olanların $(18,2 \pm 2,1)$, çocuğunun hastanede yatıs öyküsü olanların $(17,4 \pm 2,8)$ saygı desteği alt boyut puanları diğer gruplara göre daha yüksek bulundu (Tablo 5).

Araștırmaya katılan ebeveynlerin HEDÖ Kaliteli Bakım Verme Desteği alt boyut puanları ile cinsiyet, eğitim düzeyi, çaışma durumu, ekonomik durum, çocuk sayısı, çocuğun yașı, çocuğunun hastanede kalış süresi, çocuğunun yattığı ünite ve yatış öyküsü arasında istatistiksel olarak anlamlı farklılık tespit edildi $(\boldsymbol{p}<0,05)$ (Tablo 5).

Kadın ebeveynlerin $(20,1 \pm 3,5)$, eğitim düzeyi ilkokul olanIarın $(22,1 \pm 3,1)$, çalıșmayanların $(17,7 \pm 3,4)$, ekonomik durumu orta ve altı olanların $(20,5 \pm 3,7)$, çocuk sayısı 4 ve üzeri olan $(22,6 \pm 2,2)$, çocuğunun yașı 6-12 olanların $(21,1 \pm 3,3)$, çocuğunun hastanede kalıs süresi on altı-otuz gün olan-

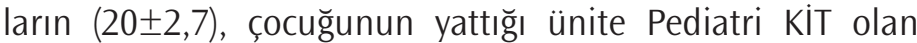
$(21,533 \pm 2,989)$, çocuğunun hastanede yatış öyküsü olanların $(20,7 \pm 3,4)$ kaliteli bakım verme alt boyut puanları diğer gruplara göre daha yüksek bulundu (Tablo 5).

Araștırmaya katılan ebeveynlerin Hemșire Ebeveyn Destek Toplam puanları ile cinsiyet, eğitim düzeyi, çalıșma durumu, ekonomik durum, çocuk sayısı, çocuğun yașı, çocuğunun hastanede kalış süresi, çocuğunun yattığı ünite ve yatış öyküsü arasında istatistiksel olarak anlamlı farklılık tespit edildi $(p<0,05)($ Tablo 5). 
Kadın ebeveynlerin $(86,9 \pm 14,1)$, eğitim düzeyi ilkokul olanların $(94,8 \pm 12,9)$, çalıșmayanların $(88,5 \pm 141)$, ekonomik durumu orta ve altı olanların $(87,3 \pm 15,4)$, çocuk sayısı 4 ve üstünde olanların $(94,1 \pm 12,6)$, çocuğunun yașı 6-12 olanların $(90,1 \pm 13,5)$, çocuğunun hastanede kalış süresi on altı-otuz gün olanların $(87,4 \pm 12,8)$, çocuğunun yattığı ünite Pediatri KiT olan ebeveynlerin $(91,8 \pm 11,4)$, çocuğunun hastanede yatıș öyküsü olanların $(88,5 \pm 13,9)$ hemșire ebeveyn destek toplam puanları diğer gruplara göre daha yüksek idi (Tablo 5).

\section{TARTIȘMA}

Aile merkezli bakım; ebeveyn, çocuk, sağlık profesyonelleri ve diğer sektörler ile iș birliği içinde çocuk sağlığının korunması, iyileștirilmesi, hastalık durumunda bakımının planlanması, uygulanması ve değerlendirilmesini kapsayan ayrıca çocuğun gelișiminde anne-baba rolünü kabul edip saygı duyan, ebeveyn güçlerini ve seçimlerini destekleyen, çocuğun hastalığında ve iyileșme sürecinde normal yașam örüntülerini geliștiren multidisipliner bir bakım sürecidir (6-8).

\section{Tablo 3. Aile Merkezli Bakım Puanları ile Hemşire Ebeveyn Destek Puanları Korelasyon Analizi}

\begin{tabular}{|c|c|c|c|c|c|c|c|c|c|}
\hline & & $\begin{array}{l}\text { Aile Merkezli } \\
\text { Bakım } \\
\text { Önemlilik }\end{array}$ & $\begin{array}{c}\text { Aile } \\
\text { Merkezli } \\
\text { Bakım } \\
\text { Tutarlııık }\end{array}$ & $\begin{array}{l}\text { Esslessme } \\
\text { Yüzdesi }\end{array}$ & $\begin{array}{l}\text { Bilgi Verme Ve } \\
\text { Illetișim Desteği }\end{array}$ & $\begin{array}{c}\text { Duygusal } \\
\text { Destek }\end{array}$ & $\begin{array}{l}\text { Saygı } \\
\text { Desteği }\end{array}$ & $\begin{array}{l}\text { Kaliteli Bakım } \\
\text { Verme }\end{array}$ & $\begin{array}{l}\text { Hemsire Ebeveyn } \\
\text { Destek Toplam }\end{array}$ \\
\hline \multirow{2}{*}{$\begin{array}{l}\text { Aile Merkezli } \\
\text { Bakım } \\
\text { Önemlilik }\end{array}$} & $r$ & 1,000 & & & & & & & \\
\hline & p & 0,000 & & & & & & & \\
\hline \multirow{2}{*}{$\begin{array}{l}\text { Aile Merkezli } \\
\text { Bakım } \\
\text { Tutarlıık }\end{array}$} & $r$ & $0,295^{* *}$ & 1,000 & & & & & & \\
\hline & $p$ & 0,000 & 0,000 & & & & & & \\
\hline \multirow[t]{2}{*}{$\begin{array}{l}\text { Eșlessme } \\
\text { Yüzdesi }\end{array}$} & $r$ & $-0,174^{*}$ & $0,753^{* *}$ & 1,000 & & & & & \\
\hline & $p$ & 0,030 & 0,000 & 0,000 & & & & & \\
\hline \multirow[t]{2}{*}{$\begin{array}{l}\text { Bilgi Verme Ve } \\
\text { Iletișism Desteğ i }\end{array}$} & $r$ & $0,282^{* *}$ & $0,713^{* *}$ & $0,567^{* *}$ & 1,000 & & & & \\
\hline & p & 0,000 & 0,000 & 0,000 & 0,000 & & & & \\
\hline \multirow[t]{2}{*}{$\begin{array}{l}\text { Duygusal } \\
\text { Destek }\end{array}$} & r & $0,226^{* *}$ & $0,673^{* *}$ & $0,554^{* *}$ & $0,833^{* *}$ & 1,000 & & & \\
\hline & $p$ & 0,005 & 0,000 & 0,000 & 0,000 & 0,000 & & & \\
\hline \multirow[t]{2}{*}{ Saygı Desteği } & $r$ & $0,197^{*}$ & $0,756^{* *}$ & $0,659^{* *}$ & $0,786^{* *}$ & $0,854^{* *}$ & 1,000 & & \\
\hline & $p$ & 0,014 & 0,000 & 0,000 & 0,000 & 0,000 & 0,000 & & \\
\hline \multirow[t]{2}{*}{$\begin{array}{l}\text { Kaliteli Bakım } \\
\text { Verme }\end{array}$} & $r$ & $0,313^{* *}$ & $0,709^{* *}$ & $0,599^{* *}$ & $0,748^{* *}$ & $0,734^{* *}$ & $0,837^{* *}$ & 1,000 & \\
\hline & $p$ & 0,000 & 0,000 & 0,000 & 0,000 & 0,000 & 0,000 & 0,000 & \\
\hline \multirow[t]{2}{*}{$\begin{array}{l}\text { Hemsire } \\
\text { Ebeveyn Destek } \\
\text { Toplam }\end{array}$} & $r$ & $0,285^{* *}$ & $0,773^{* *}$ & $0,639^{* *}$ & $0,945^{* *}$ & $0,914^{* *}$ & $0,923^{* *}$ & $0,889^{* *}$ & 1,000 \\
\hline & $p$ & 0,000 & 0,000 & 0,000 & 0,000 & 0,000 & 0,000 & 0,000 & 0,000 \\
\hline
\end{tabular}


Araștırmaya katılan ebeveynlerin aile merkezli bakım ölçeği ve eșleșme yüzdesi ve diğer bölüm puan ortalamalarının yüksek olması, ebeveynlerin sağlık kurumunda verilen aile merkezli bakım uygulamalarından memnun olduklarını göstermektedir. Ebeveyn memnuniyetinde etkili olan en önemli faktörlerden birisi de ebeveynin hastane ortamındaki gereksinimleridir. Ebeveynlerin hastane ortamındaki hem kendisinin hem de çocuğunun beklentilerinin karșılanıp karșılanmaması memnuniyetlerini etkilemektedir (9).
Altıparmak ve Arslan'ın (2015) çalıșmalarında da bu çaIıșma ile paralellik gösteren; önemlilik ve tutarlılık eșleșme oranlarının \%93 ile \%95 arasında olduğu sonucuna varılmıştır. Dunst ve arkadașlarının çalıșmasında, aile merkezli bakımın ebeveynlerin öz bakım memnuniyetini yükselten, aile çocuk bağlılığını ve davranıșlarını olumlu yönde etkileyen bir bakım modeli olduğu belirtilmiștir (10).

Erdeve'nin (2008) yapmış olduğu çalıșma aile merkezli bakımın ailenin bakım verme becerilerini ve memnuniyetini

\section{Tablo 4. Aile Merkezli Bakım Puanlarının Tanımlayıc Özelliklere Göre Farklılaşma Durumu (N=155)}

\begin{tabular}{|c|c|c|c|c|c|}
\hline & Demografik Özellikler & $\mathrm{n}$ & Aile Merkezli Bakım Önemlilik & Aile Merkezli Bakım Tutarlılık & Eșleșme Yüzdesi \\
\hline \multirow{5}{*}{ Cinsiyet } & & & Ort $\pm S S$ & Ort $\pm S S$ & $0 \mathrm{rt} \pm S S$ \\
\hline & Kadın & 124 & $32,815 \pm 2,847$ & $31,202 \pm 4,000$ & $73,502 \pm 36,782$ \\
\hline & Erkek & 31 & $32,161 \pm 3,287$ & $28,323 \pm 6,650$ & $56,682 \pm 44,795$ \\
\hline & $t=$ & & 1,107 & 3,090 & 2,177 \\
\hline & $p=$ & & 0,270 & 0,027 & 0,060 \\
\hline \multirow{5}{*}{ Yaș } & 30 Ve Altı & 42 & $32,214 \pm 3,049$ & $30,214 \pm 4,771$ & $65,306 \pm 40,547$ \\
\hline & $31-40$ & 84 & $32,726 \pm 2,943$ & $30,679 \pm 4,618$ & $70,068 \pm 37,999$ \\
\hline & 40 Üzeri & 29 & $33,241 \pm 2,760$ & $31,069 \pm 5,291$ & $77,340 \pm 39,589$ \\
\hline & $F=$ & & 1,066 & 0,284 & 0,817 \\
\hline & $p=$ & & 0,347 & 0,753 & 0,444 \\
\hline \multirow{7}{*}{$\begin{array}{l}\text { Eğitim } \\
\text { Düzeyi }\end{array}$} & illkokul & 35 & $33,571 \pm 2,671$ & $33,171 \pm 3,626$ & $89,796 \pm 24,882$ \\
\hline & Ortaokul & 26 & $31,769 \pm 2,957$ & $30,500 \pm 3,839$ & $69,780 \pm 37,542$ \\
\hline & Lise & 39 & $32,154 \pm 3,074$ & $29,692 \pm 4,974$ & $61,172 \pm 39,864$ \\
\hline & Üniversite & 55 & $32,927 \pm 2,879$ & $29,727 \pm 5,162$ & $64,156 \pm 42,669$ \\
\hline & $F=$ & & 2,522 & 4,815 & 4,362 \\
\hline & $p=$ & & 0,060 & 0,003 & 0,006 \\
\hline & Posthoc = & & & $1>2,1>3,1>4(p<0.05)$ & $1>2,1>3,1>4(p<0.05)$ \\
\hline \multirow{4}{*}{$\begin{array}{l}\text { Çalıșma } \\
\text { Durumu }\end{array}$} & Evet & 51 & $32,373 \pm 3,092$ & $28,588 \pm 5,913$ & $58,543 \pm 43,543$ \\
\hline & Hayıır & 104 & $32,837 \pm 2,866$ & $31,625 \pm 3,734$ & $75,824 \pm 35,335$ \\
\hline & $\mathrm{t}=$ & & $-0,923$ & $-3,894$ & $-2,645$ \\
\hline & $p=$ & & 0,358 & 0,001 & 0,016 \\
\hline \multirow{5}{*}{$\begin{array}{l}\text { Ekonomik } \\
\text { Durumu }\end{array}$} & Çok Iyi & 10 & $32,900 \pm 2,885$ & $29,900 \pm 4,202$ & $58,571 \pm 43,877$ \\
\hline & İyi & 50 & $32,640 \pm 3,022$ & $29,740 \pm 5,038$ & $64,286 \pm 42,147$ \\
\hline & Orta Ve Altı & 95 & $32,684 \pm 2,933$ & $31,168 \pm 4,642$ & $74,436 \pm 36,385$ \\
\hline & $F=$ & & 0,032 & 1,607 & 1,596 \\
\hline & $p=$ & & 0,968 & 0,204 & 0,206 \\
\hline \multirow{6}{*}{$\begin{array}{l}\text { Çocuk } \\
\text { Sayısı }\end{array}$} & 1 & 45 & $32,711 \pm 2,928$ & $29,489 \pm 4,718$ & $58,095 \pm 42,247$ \\
\hline & 2 & 65 & $32,462 \pm 3,037$ & $30,815 \pm 5,123$ & $73,407 \pm 36,933$ \\
\hline & 3 & 29 & $32,414 \pm 3,134$ & $30,931 \pm 4,276$ & $73,892 \pm 39,874$ \\
\hline & 4 Ve Üzeri & 16 & $34,000 \pm 1,932$ & $32,500 \pm 3,742$ & $83,929 \pm 28,985$ \\
\hline & $F=$ & & 1,282 & 1,778 & 2,409 \\
\hline & $p=$ & & 0,283 & 0,154 & 0,069 \\
\hline
\end{tabular}




\begin{tabular}{|c|c|c|c|c|c|}
\hline \multirow{4}{*}{$\begin{array}{l}\text { Çocuğun } \\
\text { Cinsiyeti }\end{array}$} & KIZ & 73 & $32,836 \pm 2,944$ & $30,164 \pm 5,175$ & $64,384 \pm 42,467$ \\
\hline & Erkek & 82 & $32,549 \pm 2,949$ & $31,037 \pm 4,364$ & $75,261 \pm 34,996$ \\
\hline & $t=$ & & 0,605 & $-1,138$ & $-1,747$ \\
\hline & $p=$ & & 0,546 & 0,257 & 0,086 \\
\hline \multirow{8}{*}{$\begin{array}{l}\text { Çocuğun } \\
\text { Yașı }\end{array}$} & Sifır-bir & 28 & $32,393 \pm 2,807$ & $30,357 \pm 4,262$ & $69,898 \pm 38,163$ \\
\hline & Bir-üç & 33 & $32,424 \pm 3,269$ & $29,273 \pm 5,369$ & $57,143 \pm 42,408$ \\
\hline & Üç-altı & 30 & $31,700 \pm 3,131$ & $29,433 \pm 5,673$ & $69,524 \pm 37,840$ \\
\hline & Altı-oniki & 38 & $33,211 \pm 2,858$ & $32,132 \pm 3,520$ & $76,692 \pm 35,059$ \\
\hline & Oniki-onsekiz & 26 & $33,692 \pm 2,187$ & $31,808 \pm 4,327$ & $78,022 \pm 40,453$ \\
\hline & $F=$ & & 2,100 & 2,608 & 1,474 \\
\hline & $p=$ & & 0,084 & 0,038 & 0,213 \\
\hline & PostHoc= & & & $4>2,5>2,4>3(p<0.05)$ & \\
\hline \multirow{7}{*}{$\begin{array}{l}\text { Çocuğun } \\
\text { Kalış } \\
\text { Süresi }\end{array}$} & Üç-yedi & 50 & $32,800 \pm 2,969$ & $28,700 \pm 5,818$ & $56,286 \pm 45,580$ \\
\hline & Sekiz-onbeș & 25 & $31,920 \pm 2,929$ & $29,680 \pm 3,934$ & $65,714 \pm 38,465$ \\
\hline & 0naltı-otuz & 28 & $32,714 \pm 3,264$ & $32,214 \pm 3,785$ & $72,959 \pm 36,750$ \\
\hline & 0tuz Üzeri & 52 & $32,923 \pm 2,757$ & $32,077 \pm 3,693$ & $84,066 \pm 27,813$ \\
\hline & $F=$ & & 0,700 & 6,274 & 4,814 \\
\hline & $p=$ & & 0,553 & 0,000 & 0,003 \\
\hline & PostHoc = & & & $3>1,4>1,3>2,4>2(p<0.05)$ & $4>1,4>2(p<0.05)$ \\
\hline \multirow{6}{*}{$\begin{array}{c}\text { Çocuğun } \\
\text { Yattığı } \\
\text { Ünite }\end{array}$} & Pediatri Servisi & 52 & $32,135 \pm 3,016$ & $28,462 \pm 4,976$ & $54,670 \pm 43,157$ \\
\hline & Pediatri Kit & 77 & $32,922 \pm 2,937$ & $32,299 \pm 3,498$ & $82,746 \pm 29,253$ \\
\hline & Pybü Ve Nıcu & 26 & $33,077 \pm 2,741$ & $30,000 \pm 5,790$ & $63,736 \pm 43,749$ \\
\hline & $F=$ & & 1,399 & 11,766 & 9,413 \\
\hline & $p=$ & & 0,250 & 0,000 & 0,000 \\
\hline & Posthoc $=$ & & & $2>1,2>3(p<0.05)$ & $2>1,2>3(p<0.05)$ \\
\hline \multirow{4}{*}{$\begin{array}{l}\text { Yatış } \\
\text { Öyküsü }\end{array}$} & Evet & 80 & $33,063 \pm 2,905$ & $31,525 \pm 4,340$ & $74,464 \pm 36,771$ \\
\hline & Hayıı & 75 & $32,280 \pm 2,943$ & $29,667 \pm 5,039$ & $65,524 \pm 40,887$ \\
\hline & $t=$ & & 1,665 & 2,465 & 1,433 \\
\hline & $p=$ & & 0,098 & 0,015 & 0,154 \\
\hline
\end{tabular}

yükselten, Schepp'in yapmış olduğu çalıșmada da öz yeterlilik duygusunu arttıran, ailelerin çocuklarının sağlık durumuna ilișkin yeterli bilgiye sahip olarak stresini azaltan, çocukların iyileșme sürecini arttıran bir bakım modeli olduğu belirtilmektedir (11).

Oktay yapmış olduğu çalıșmasında, ebeveynlerin çocuğunun hastanede yatma sürecinde çocuğun genel durumu, tanı ve tedavisi hakkında bilgilendirilmek istediklerini ve bilgilendirilmenin ebeveyn ve çocuklarının anksiyetesini azalttığını belirlemiștir (9).

Miles, Carlson ve Brunssen, hastanede yatan çocuğun ebeveyni için destekleyici hemșireliğin; destekleyici olan bir ilișki ve süreklilik sağlayan bilgi sunulması, olumlu, teșvik edici yorum ve değerlendirme yapılarak ebeveyn rolünün sürdürülmesi, duygusal destek verilip ve çocuğa kaliteli hemşirelik bakımı sağlanması biçiminde önemini vurgulamıșlardır (12).

Özcan tarafından yapılan çalışmada da benzer şekilde çocukların cinsiyeti, yaş grupları, ekonomik durumları gibi demografik özelliklerin aile merkezli bakım uygulamaları üzerine etkili birer faktör olmadığı belirtilmiștir (14).

Özkan ve arkadașlarının yaptığı çalışmada da hemșirelere göre ebeveynin bakıma katılımını etkileyen özellikler incelenmiş olup, ebeveyn cinsiyetinin ebeveynin bakıma katılımını büyük ölçüde belirleyen özelliklerden biri olduğu bulunmuştur (15). Bu araștırmaya paralellik gösteren Bağ ve Uysal'ın ayrı ayrı yaptıkları çalışmaları incelendiğinde çocuğun yaşı arttıkça ebeveynlerin aldıkları bakımdan memnuniyetlerinin de arttığı belirlenmiștir $(12,13)$.

Arıkan ve arkadașlarının çalıșmasında ebeveynlerin eğitim durumları yükseldikçe ebeveyn katılımı, iletişim ile teknik 
Tablo 5. Hemşire Eheveyn Destek Puanlarınun Tanımlayıc Özelliklere Göre Farkllaşma Durumu (N=155)

\begin{tabular}{|c|c|c|c|c|c|c|c|}
\hline & $\begin{array}{l}\text { Demografik } \\
\text { Özellikler }\end{array}$ & $n$ & $\begin{array}{c}\text { Bilgi Verme ve Illetişim } \\
\text { Desteği }\end{array}$ & Duygusal Destek & Saygı Desteği & Kaliteli Bakım Verme & $\begin{array}{c}\text { Hemșire Ebeveyn Destek } \\
\text { Toplam }\end{array}$ \\
\hline \multirow{5}{*}{ Cinsiyet } & & & $0 \mathrm{rt} \pm S S$ & $0 \mathrm{rt} \pm S S$ & $0 \mathrm{rt} \pm S S$ & $0 \mathrm{rt} \pm S S$ & $0 \mathrm{rt} \pm S S$ \\
\hline & Kadın & 124 & $37,436 \pm 6,531$ & $12,258 \pm 2,575$ & $17,065 \pm 2,901$ & $20,177 \pm 3,520$ & $86,936 \pm 14,160$ \\
\hline & Erkek & 31 & $34,161 \pm 6,639$ & $10,194 \pm 3,167$ & $14,484 \pm 3,696$ & $17,774 \pm 4,177$ & $76,613 \pm 16,645$ \\
\hline & $t=$ & & 2,488 & 3,806 & 4,181 & 3,272 & 3,502 \\
\hline & $p=$ & & 0,014 & 0,000 & 0,000 & 0,001 & 0,001 \\
\hline \multirow{5}{*}{ Yaș } & 30 Ve Altı & 42 & $35,071 \pm 7,290$ & $11,452 \pm 2,847$ & $16,048 \pm 3,268$ & $18,548 \pm 3,590$ & $81,119 \pm 15,655$ \\
\hline & $31-40$ & 84 & $37,441 \pm 5,971$ & $12,119 \pm 2,613$ & $16,881 \pm 2,996$ & $20,155 \pm 3,652$ & $86,595 \pm 13,833$ \\
\hline & 40 Üzeri & 29 & $37,345 \pm 7,389$ & $11,621 \pm 3,321$ & $16,310 \pm 3,809$ & $20,035 \pm 4,136$ & $85,310 \pm 17,769$ \\
\hline & $F=$ & & 1,921 & 0,896 & 1,027 & 2,746 & 1,850 \\
\hline & $p=$ & & 0,150 & 0,410 & 0,361 & 0,067 & 0,161 \\
\hline \multirow{7}{*}{ Eğitim Düzeyi } & illkokul & 35 & $40,829 \pm 5,978$ & $13,400 \pm 2,172$ & $18,457 \pm 2,501$ & $22,143 \pm 3,164$ & $94,829 \pm 12,942$ \\
\hline & Ortaokul & 26 & $35,654 \pm 7,144$ & $12,115 \pm 2,338$ & $17,346 \pm 2,727$ & $20,731 \pm 3,595$ & $85,846 \pm 14,251$ \\
\hline & Lise & 39 & $35,205 \pm 5,917$ & $11,256 \pm 2,844$ & $15,846 \pm 3,192$ & $18,410 \pm 3,633$ & $80,718 \pm 14,266$ \\
\hline & Üniversite & 55 & $35,855 \pm 6,473$ & $11,146 \pm 3,015$ & $15,455 \pm 3,321$ & $18,564 \pm 3,479$ & $81,018 \pm 14,986$ \\
\hline & $\mathrm{F}=$ & & 6,209 & 5,834 & 8,348 & 10,308 & 8,189 \\
\hline & $P=$ & & 0,001 & 0,001 & 0,000 & 0,000 & 0,000 \\
\hline & Posthoc = & & $\begin{array}{c}1>2,1>3,1>4 \\
(p<0.05)\end{array}$ & $\begin{array}{c}1>3,1>4 \\
(p<0.05)\end{array}$ & $\begin{array}{c}1>3,1>4,2 \\
>4(p<0.05)\end{array}$ & $\begin{array}{c}1>3,2>3,1>4 \\
2>4(p<0.05)\end{array}$ & $\begin{array}{c}1>2,1>3,1>4 \\
(p<0.05)\end{array}$ \\
\hline \multirow{4}{*}{$\begin{array}{l}\text { Çalıșma } \\
\text { Durumu }\end{array}$} & Evet & 51 & $34,216 \pm 6,341$ & $10,628 \pm 2,821$ & $14,902 \pm 3,324$ & $17,706 \pm 3,472$ & $77,451 \pm 14,862$ \\
\hline & Hayır & 104 & $38,039 \pm 6,479$ & $12,442 \pm 2,629$ & $17,356 \pm 2,876$ & $20,673 \pm 3,535$ & $88,510 \pm 14,069$ \\
\hline & $t=$ & & $-3,475$ & $-3,942$ & $-4,738$ & $-4,939$ & $-4,513$ \\
\hline & $p=$ & & 0,001 & 0,000 & 0,000 & 0,000 & 0,000 \\
\hline \multirow{6}{*}{$\begin{array}{l}\text { Ekonomik } \\
\text { Durumu }\end{array}$} & Çok Iyi & 10 & $34,300 \pm 2,669$ & $10,300 \pm 2,584$ & $13,800 \pm 2,486$ & $16,900 \pm 2,132$ & $75,300 \pm 8,152$ \\
\hline & İyi & 50 & $35,980 \pm 6,403$ & $11,560 \pm 2,704$ & $15,920 \pm 3,263$ & $18,600 \pm 3,597$ & $82,060 \pm 14,714$ \\
\hline & Orta e Altı & 95 & $37,463 \pm 7,013$ & $12,158 \pm 2,856$ & $17,168 \pm 3,097$ & $20,568 \pm 3,726$ & $87,358 \pm 15,475$ \\
\hline & $F=$ & & 1,564 & 2,388 & 6,775 & 8,081 & 4,279 \\
\hline & $p=$ & & 0,213 & 0,095 & 0,002 & 0,000 & 0,016 \\
\hline & Posthoc = & & & & $\begin{array}{c}3>1,3>2 \\
(p<0.05)\end{array}$ & $\begin{array}{c}3>1,3>2 \\
\quad(p<0.05)\end{array}$ & $3>1,3>2(p<0.05)$ \\
\hline \multirow{7}{*}{ Çocuk Sayısı } & 1 & 45 & $35,200 \pm 6,402$ & $11,378 \pm 2,790$ & $15,911 \pm 3,281$ & $18,378 \pm 3,446$ & $80,867 \pm 14,254$ \\
\hline & 2 & 65 & $36,923 \pm 6,627$ & $11,708 \pm 2,967$ & $16,554 \pm 3,187$ & $19,739 \pm 3,747$ & $84,923 \pm 15,331$ \\
\hline & 3 & 29 & $37,069 \pm 6,718$ & $12,035 \pm 2,666$ & $16,690 \pm 3,465$ & $20,035 \pm 4,119$ & $85,828 \pm 15,931$ \\
\hline & 4 ve Üzeri & 16 & $40,125 \pm 6,642$ & $13,375 \pm 2,125$ & $18,063 \pm 2,516$ & $22,625 \pm 2,247$ & $94,188 \pm 12,629$ \\
\hline & $\mathrm{F}=$ & & 2,271 & 2,126 & 1,798 & 5,588 & 3,213 \\
\hline & $p=$ & & 0,083 & 0,099 & 0,150 & 0,001 & 0,025 \\
\hline & Posthoc = & & & & & $\begin{array}{c}4>1,4>2,4>3 \\
\quad(p<0.05)\end{array}$ & $4>1,4>2(p<0.05)$ \\
\hline
\end{tabular}




\begin{tabular}{|c|c|c|c|c|c|c|c|}
\hline \multirow{4}{*}{$\begin{array}{l}\text { Çocuğun } \\
\text { Cinsiyeti }\end{array}$} & KIZ & 73 & $36,206 \pm 6,799$ & $11,493 \pm 2,853$ & $16,123 \pm 3,436$ & $19,370 \pm 4,138$ & $83,192 \pm 16,080$ \\
\hline & Erkek & 82 & $37,293 \pm 6,537$ & $12,159 \pm 2,764$ & $16,927 \pm 3,013$ & $19,988 \pm 3,412$ & $86,366 \pm 14,320$ \\
\hline & $t=$ & & $-1,014$ & $-1,473$ & $-1,551$ & $-1,018$ & $-1,300$ \\
\hline & $p=$ & & 0,312 & 0,143 & 0,126 & 0,310 & 0,196 \\
\hline \multirow{8}{*}{ Çocuğun Yaşı } & Sifır-bir & 28 & $35,536 \pm 7,280$ & $11,500 \pm 2,950$ & $16,000 \pm 3,453$ & $18,857 \pm 3,659$ & $81,893 \pm 15,576$ \\
\hline & Bir-üç & 33 & $34,667 \pm 6,599$ & $11,061 \pm 2,957$ & $15,667 \pm 3,247$ & $18,333 \pm 4,036$ & $79,727 \pm 15,255$ \\
\hline & Üç-altı & 30 & $35,100 \pm 6,488$ & $11,267 \pm 2,703$ & $16,200 \pm 3,167$ & $19,200 \pm 3,231$ & $81,767 \pm 14,151$ \\
\hline & Altı-oniki & 38 & $38,895 \pm 5,769$ & $12,763 \pm 2,583$ & $17,395 \pm 3,018$ & $21,105 \pm 3,303$ & $90,158 \pm 13,534$ \\
\hline & $\begin{array}{l}\text { On iki-on } \\
\text { sekiz }\end{array}$ & 26 & $39,654 \pm 5,993$ & $12,539 \pm 2,611$ & $17,423 \pm 3,088$ & $20,846 \pm 4,017$ & $90,462 \pm 15,166$ \\
\hline & $F=$ & & 4,009 & 2,563 & 2,085 & 3,731 & 3,810 \\
\hline & $p=$ & & 0,004 & 0,041 & 0,086 & 0,006 & 0,006 \\
\hline & PostHoc= & & $\begin{array}{c}4>1,5>1,4>2 \\
5>2,4>3,5>3 \\
\quad(p<0.05)\end{array}$ & $\begin{array}{c}4>2,5>2,4>3 \\
(p<0.05)\end{array}$ & & $\begin{array}{c}4>1,5>1,4>2,5 \\
>2,4>3(p<0.05)\end{array}$ & $\begin{array}{c}4>1,5>1,4>2,5>2 \\
4>3,5>3(p<0.05)\end{array}$ \\
\hline \multirow{7}{*}{$\begin{array}{l}\text { Çocuğun Kalıș } \\
\text { Süresi }\end{array}$} & Üç-yedi & 50 & $34,300 \pm 6,215$ & $10,960 \pm 2,642$ & $14,760 \pm 3,133$ & $17,640 \pm 3,022$ & $77,660 \pm 13,915$ \\
\hline & Sekiz-onbes & 25 & $34,640 \pm 6,969$ & $10,600 \pm 3,367$ & $15,280 \pm 3,446$ & $18,440 \pm 4,243$ & $78,960 \pm 16,635$ \\
\hline & Onalti-otuz & 28 & $37,893 \pm 6,070$ & $12,321 \pm 2,374$ & $17,250 \pm 2,757$ & $20,000 \pm 2,722$ & $87,464 \pm 12,839$ \\
\hline & Otuz Üzeri & 52 & $39,596 \pm 6,124$ & $13,039 \pm 2,417$ & $18,500 \pm 2,110$ & $22,115 \pm 3,294$ & $93,250 \pm 12,308$ \\
\hline & $F=$ & & 7,333 & 7,490 & 17,303 & 17,192 & 13,004 \\
\hline & $p=$ & & 0,000 & 0,000 & 0,000 & 0,000 & 0,000 \\
\hline & PostHoc= & & $\begin{array}{c}3>1,4>1,4>2 \\
\quad(p<0.05)\end{array}$ & $\begin{array}{c}3>1,4>1,3>2, \\
4>2(p<0.05)\end{array}$ & $\begin{array}{c}3>1,4>1 \\
3>2,4>2 \\
(p<0.05)\end{array}$ & $\begin{array}{c}3>1,4>1,4>2 \\
4>3(p<0.05)\end{array}$ & $\begin{array}{c}3>1,4>1,3>2,4>2 \\
(p<0.05)\end{array}$ \\
\hline \multirow{6}{*}{$\begin{array}{l}\text { Çocuğun } \\
\text { Yattığı Ünite }\end{array}$} & $\begin{array}{l}\text { Pediatri } \\
\text { Servisi }\end{array}$ & 52 & $32,923 \pm 6,142$ & $10,173 \pm 2,888$ & $14,231 \pm 2,874$ & $17,192 \pm 3,332$ & $74,519 \pm 14,103$ \\
\hline & Pediatri Kit & 77 & $39,182 \pm 5,873$ & $12,870 \pm 2,185$ & $18,260 \pm 2,022$ & $21,533 \pm 2,989$ & $91,844 \pm 11,431$ \\
\hline & Pybü Ve Nıcu & 26 & $37,385 \pm 6,518$ & $12,154 \pm 2,866$ & $16,115 \pm 3,840$ & $19,269 \pm 3,769$ & $84,923 \pm 15,783$ \\
\hline & $F=$ & & 16,634 & 17,499 & 35,193 & 28,037 & 26,921 \\
\hline & $p=$ & & 0,000 & 0,000 & 0,000 & 0,000 & 0,000 \\
\hline & Posthoc= & & $2>1,3>1(p<0.05)$ & $\begin{array}{c}2>1,3>1 \\
(p<0.05)\end{array}$ & $\begin{array}{l}2>1,3>1,2 \\
>3(p<0.05)\end{array}$ & $\begin{array}{c}2>1,3>1,2>3 \\
(p<0.05)\end{array}$ & $\begin{array}{c}2>1,3>1,2>3 \\
\quad(p<0.05)\end{array}$ \\
\hline \multirow{4}{*}{ Yatış Öyküsü } & Evet & 80 & $37,963 \pm 6,653$ & $12,425 \pm 2,494$ & $17,425 \pm 2,854$ & $20,725 \pm 3,438$ & $88,538 \pm 13,990$ \\
\hline & Hауıг & 75 & $35,520 \pm 6,479$ & $11,227 \pm 3,021$ & $15,613 \pm 3,369$ & $18,600 \pm 3,824$ & $80,960 \pm 15,567$ \\
\hline & $\mathrm{t}=$ & & 2,313 & 2,700 & 3,620 & 3,642 & 3,191 \\
\hline & $p=$ & & 0,022 & 0,008 & 0,000 & 0,000 & 0,002 \\
\hline
\end{tabular}

becerilerinin ve memnuniyet düzeyinin arttığı belirlenmiştir (16). Arıkan ile Ulus'un yaptı̆̆ı benzer iki farklı çalıșmada, hastanede kalıș süresi arttıkça bakımdan memnuniyet düzeyinin anlamlı derecede düștügü saptanmıștır $(16,17)$.

Araştırmada Pediatri KiT ünitesinde yatan çocukları olan ebeveynlerin puan ortalamalarının diğer gruplara göre yüksek olmasının sebebinin hastanede kalıș süresinin daha uzun olmasından kaynaklı olabileceği düșünülmüștür. Hastanede uzun süre kalan ebeveyn hastane ortamına uyum açısından daha sağııkı bir süreç geçirdiğinden aile merkezli bakıma yönelik uygulamalarda hemșire ile iletișime de adaptasyon sağlamıș olur ve bunun sonucunda da hemșirenin çocuğuna ayırdığı zamandan, ebeveynin kendisinin de dahil olduğu aile merkezli bakımdan memnuniyetinin artacă̆ı düșünülmektedir. 
Hasta çocuğa sahip ailede bakımdan sorumlu kiși genellikle annelerdir, babalar ise daha çok yardımcı rolde görev almaktadır (18). Kain ve Wang'ın ebeveynlerin çocukları hakkında bilgi istemeleri ile ilgili yaptıkları araştırmada ise, ebeveynin eğitim düzeyi arttıkça, çocukları hakkında bilgi almayı isteme ve soru sorma durumlarının arttığını belirlemişlerdir (19). Altınay'ın yaptığı bir çalıșmada, aşırı anneliğin, așırı kontrol, müdahalecilik, çocuktan bağımlı, aktif ve çalışkan olmasını isteme, annenin son derece fedakâr olması ve çocuğunun da bunu anlamasına inanma gibi konuları kapsadığı belirtilmektedir. Herhangi bir iște çalıșmaya ayrı bir enerji ve zaman harcamayan ev hanımlarının, çocuklarına daha fazla vakit ayırmaları ve daha bağımlı ilișkiler kurması sonucunda da bilgi isteme oranlarının yüksek olduğu ifade edilmiștir (20). Küçükkocabaș ve Dönmez’in bu çalıșmaya paralellik gösteren araștırmasında hastanede yatış zamanı uzadıkça çocuk ile ebeveynin primer hemșiresi ile iletișiminin de artması ile bilgi alma desteği artacağı ayrıca ebeveynin hemșirelerin iş yüklerinin fazla olduğunu görerek beklentisinin azalacağı düșüncesiyle memnuniyet düzeyinin yükseldiği belirtilmiștir (21).

Avis ve Reardon'ın yaptıkları çalıșmada ebeveynler, hemşirelerin kendilerine yeterli duygusal destek sağlamadığını ifade etmișlerdir (22). Bunun sebebinin yıllar geçtikçe aile merkezli bakım anlayıșının yavaș yavaș kabul ediliyor olması olarak düşünülmüștür. Koç ve ark.'nın çalıșmasında, daha önce hastaneye yatırılan çocuk ve ebeveynlerin memnuniyet düzeyleri daha önce hastaneye yatmamış hastalara göre daha yüksek bulunmuștur (23).

Çocuğunun bakımında her zaman birincil görev üstlenen anne, işgücüne katılmasıyla beraber aile içi rollerde değișim ve paylașımı gündeme getirmiștir. Hemșire annenin bu yönünü dikkate alarak, çocuğunun bakımında diğer ebeveynleri de bakıma katılmaya teșvik etmelidir. Hemșire, ebeveynin destek kaynaklarını görmesini sağlayıp aynı zamanda kadının aile içi rol değișimine de destek vermiș olur (24). Kadın ebeveynlerin eğitim seviyesinin artması, çalıșma yaşamına katılması gibi değişen nedenlere eșdeğer olarak aile içindeki konumu ve çocuğunu yetiștirmesindeki etkileri de değișim göstermiștir (17). Eğitim düzeyi arttıkça ebeveyn kendini daha iyi geliștirdiği ve toplumda daha çok söz sahibi olduğundan sağlık çalıșanından saygı desteği beklentisi düșmektedir. ÇaIışan ebeveynin rol ve sorumluluğu çalışmayan ebeveyne göre daha fazladır. Çalıșan ebeveynin eğitim düzeyi ve sosyal çevresinin daha geniș olduğu düșünülürse buna bağlı olarak hemșireden beklediği saygı desteğinin daha düşük olabileceği düşünülmektedir. Ebeveyn ve çocuğunun yaşam kalitesini etkileyen kaynaklardan biri olan gelir, yașamla ilgili istek ve intiyaçları karșılamada kullanılan önemli bir kaynaktır. Hastanede tedavi süreci ebeveyni maddi açıdan sıkıntıya sokan bir süreçtir. Ebeveynlerin hastanede kalmaları desteklenmeli; ebeveynlerin hastanede çocuğunun yanında kalırken iș yerlerinden izin taleplerinin onaylanması ve hastanede kaldıkları sürece maddi olarak desteklenmeleri sağlanmalıdır (18). Küçükkocabaș ve Dönmez'in araștırmasında hastanede kalış zamanı uzadıkça çocuk, ebeveyn ve hemșire iletișiminin güçlenmesi ile bilgi paylaşımının fazlalaştığı ayrıca ebeveynlerin hemșirenin iş yüklerinin çok olduğunu görmeleri sebebi ile beklentilerinin azaldığı düșüncesiyle memnuniyet düzeylerinin yükseldiği belirtilmektedir (21).

Broger'in yaptığı çalıșmada da kadın ebeveynlerin bakıma dahil edilme ve bakımdan memnun olma puanları bu çalışmayı destekler nitelikte yüksek bulunmuștur (25). Araştırmaya paralel olarak Carey ve ark. çalıșmalarında, düșük sosyoekonomik düzeyin bakım veren kișinin negatif olarak etkilenmesine neden olduğu bildirilmiștir. Oberst ve ark. ise yapmış oldukları çalıșmalarında, düşük sosyo-ekonomik düzeyin bakım vermedeki davranıșlarda değişimlere neden olduğunu açıklamışlardır (26). Çocuk sayısı arttıkça çocuğuna ayıracağı vakti azalan ebeveynin bakım desteğine daha çok ihtiyaç duyabileceği ile ilişkili olduğu düşünülmektedir. Kürtüncü ve ark. tarafından yapılan çalıșmada da ebeveynlerin çocuk sayısı ile memnuniyet puan ortalamaları arasında anlamlı fark belirlenmiștir. Beș ve üzeri çocuğa sahip ebeveynlerin memnuniyet puan ortalamalarının anlamlı derecede daha yüksek olduğu saptanmıștır (21). Dur ve ark.'nın (2016) çalıșmasında ise hemșirelere ebeveynlerin çocuğunun bakımına katılımına ilișkin tutum ve davranıșlarını belirlemek üzere çeșitli ifadeler yöneltilmiștir. Genel anlamda hemșireler çocuk ve ebeveynleri bir bütün olarak gördükleri sonucuna ulașmıșlar, fakat ebeveynin çocuğunun yanında olmasının sorun oluşturabileceği durumların/zamanların olabileceğini düşündüklerini ifade ettikleri de belirlenmiștir (27). Tanır ve Kuğuoğlu'nun yapmış olduğu araștırmada annelerin meslekleri ile memnuniyet ölçeğinin genel memnuniyet, bilgi, teknik beceriler alt boyutları puan ortalamaları arasında anlamlı fark saptanmıștır. Çalıșmayan ebeveynlerin bu üç alt boyut puanlarının daha yüksek olduğu belirtilmiștir (21). Arıkan ve arkadașlarının yapmış olduğu araștırmada, çocuğunun hastalığının maddi yüklerini arttırdığını ifade eden ebeveynlerin memnuniyet düzeylerinin daha düșük ve destek beklentilerinin daha yüksek olduğu belirlenmiștir (16). Reyhani ve ark.'larının 6-12 yaș arası çocuk ve ebeveynleriyle yaptığı bir çalıșmada, çocuklarına eğitim desteği verilen ebeveynlerin anksiyete düzeyi, çocuklarına eğitim desteği verilmeyen ebeveynlerin anksiyete düzeyinden çok daha düșük bulunmuştur (28).

\section{SONUC}

Hastane yatış sürecinde verilen aile merkezli bakım ile ebeveynlere sağlanan destek düzeyi arasında pozitif yönlü bir ilișkinin bulunduğu çalıșma sonucunda; 
Hemșireler tarafından bakıma ailenin katılımı sağlanarak ebeveynlerin gereksinim duyduğu konuda destek verilmesi, ebeveynlere çocuklarının sağlık durumu hakkında eğitim düzeyleri de dikkate alınarak düzenli, anlașılır ve kısa bilgilendirmeler yapılması, ebeveyn ve çocuklarının hastaneye yatışları sırasında anksiyetelerinin azaltılması için kliniğe oryantasyon sağlanması, pediatri servislerinde ve yoğun bakım ünitelerinde hemşire sayısı artırılarak kaliteli bakım verilmesi, ebeveynlere sağlanan destek düzeyinin belirlenmesine yönelik daha fazla araștırma yapılması, pediatri servisleri ve yoğun bakım ünitelerinde kullanılacak hastane yönetimi tarafından aile merkezli bakım protokolleri olușturulması ve uygulamaya konması önerilmektedir.

\section{BILDIRIMLER}

Değerlendirme

Dıș danıșmanlarca değerlendirilmiștir.

Çıkar Çatıșması

Yazarlar bu makale ile ilgili herhangi bir çıkar çatıșması bildirmemișlerdir.

Finansal Destek

Yazarlar bu makale ile ilgili herhangi bir malî destek kullanımı bildirmemișlerdir.

Etik Beyan

Bu çalıșma için İstanbul Medipol Üniversitesi Girișimsel Olmayan Klinik Araștırmalar Etik Kurulundan 30.09.2019 tarih ve 10840098 sayılı yazı ile izin alınmıș olup Helsinki Bildirgesi kriterleri göz önünde bulundurulmuștur.

\section{KAYNAKLAR}

1. Hockenberry MJ, Wilson D, Winkelstein M, Kline N. Wong's Nursing Care of Infants and Children. 7th ed. Elsevier Press. 2008. p. 39.

2. Tüfekci Güdücü F, Tosun A. Cocuk Kliniklerinde Aile Merkezli Bakım Uygulamaları. Artic J Anatolia Nurs Heal Sci. 2015;2(18). https://doi.org/10.17049/ahsbd.29902

3. Shields L, Nixon J. Hospital Care Of Children In Four Countries. J Adv Nurs. 2005 Mar 1;45(5):475-86. https://doi.org/10.1046/ j.1365-2648.2003.02930.x

4. Oktay H. Bir Üniversite Hastanesinin Çocuk Servislerinde Verilen Bakımın Aile Merkezli Bakım Yönünden İncelenmesi Ve Anne Görüşlerinin Belirlenmesi. Hacettepe Üniversitesi Sağlık Bilim Fakültesi Hemşirelik Derg. 2009;16(1):11-24.

5. Niela-Vilén H, Axelin A, Salanterä S, Melender HL. InternetBased Peer Support For Parents: A Systematic Integrative Review. Vol. 51, International Journal of Nursing Studies. Elsevier Ltd; 2014. p. 1524-37. https://doi.org/10.1016/j. ijnurstu.2014.06.009

6. Curley MAQ, Hunsberger M, Harris SK. Psychometric Evaluation of the Family-Centered Care Scale for Pediatric Acute Care Nursing. Nurs Res. 2013 May;62(3):160-8. https:// doi.org/10.1097/NNR.0b013e318286d64b
7. Teksöz E, Ocakçı AF. Çocuk Hemşireliğinde Sanat Uygulamaları. Dokuz Eylül Üniversitesi Hemşirelik Yüksekokulu Derg. 2014;7(2):19-123.

8. Altıparmak D, Deniz. Aile Merkezli Bakım Ölçeği'nin Türkçe'ye Uyarlanması Geçerlik Ve Güvenirlik Çalıșması. 2015

9. Anabilim P, Deneysel D, Dalı PB, Oktay B, Lisans Tezi Y. Hacettepe Üniversitesi Sosyal Bilimler Enstitüsü Hazırlama Türü Ve Duygusal Bağlamın Dikkatsizlik Körlügü Üzerindeki Etkisinin İncelenmesi: Bir Göz İzleme Çalıșması. 2014.

10. Dunst CJ, Trivette CM, Hamby DW. Meta-Analysis Of FamilyCentered Helpgiving Practices Research. Ment Retard Dev Disabil Res Rev. 2007 Jan 1;13(4):370-8. https://doi. org/10.1002/mrdd.20176

11. Davidson JE, Aslakson RA, Long AC, Puntillo KA, Kross EK, Hart J, et al. Guidelines for Family-Centered Care in the Neonatal, Pediatric, and Adult ICU. Crit Care Med. 2017 Jan 1;45(1):10328. https://doi.org/10.1097/CCM.0000000000002169

12. Oktay H. Bir Üniversite Hastanesinin Cocuk Servislerinde Verilen Bakımın Aile Merkezli Bakım Yönünden İncelenmesi Ve Anne Görüşlerinin Belirlenmesi. Hacettepe Üniversitesi Sağlık Bilim Fakültesi Hemşirelik Dergisi. 2009;16(1):11-24.

13. Schaffer P, Vaughn G, Kenner C, Donohue F, Longo A. Revision of A Parent Satisfaction Survey Based On The Parent Perspective. J Pediatr Nurs. 2010 Dec 1;15(6):373-7. https:// doi.org/10.1053/jpdn.2000.16713

14. Özcan F, Uysal G. Pediatri Servislerinde Uygulanan Hemşirelik Yaklaşımının Aile Merkezli Bakım Açısından Değerlendirilmesi. 2017.

15. Özkan S, Tas Arslan F. Hemşirelerin Hastanede Yatan Çocuğun Bakımına Ebeveyn Katılımı Hakkında Görüşleri. Artic J Contemp Med. 2017;7(4). https://doi.org/10.16899/ gopctd. 359798

16. Arıkan D, Saban F, Gürarslan Baş N. Çocuğu Hastanede Yatan Ebeveynlerin Hastaneye Ve Sağlık Bakımına Yönelik Memnuniyet Düzeyleri. Çocuk Hast Derg. 2014;4(2):109-16.

17. Ulus B, Kublay G. PedsQL Sağlık Bakımı Ebeveyn Memnuniyet Ölçeğinin Türkçe'ye Uyarlanması. Acıbadem Üniversitesi Sağlık Bilim Derg. 2012.

18. Aykanat B, Gözen D. Çocuk Sağlığı Hemşireliğinde Aile Merkezli Bakım Yaklaşımı. Vol. 3, Gümüșhane Üniversitesi Sağlık Bilimleri Dergisi /Gümüşhane University Journal of Health Sciences. 2014.

19. Silbert BS, Scott DA. Informed Consent in Patients with Frailty Syndrome. Anesth Analg. 2020;1474-81. https://doi. org/10.1213/ANE.0000000000004629

20. Altınay D. Çalışan ve Çalıșmayan Annelerin Başa Cııma Tutumları ve Çocuk Yetiștirme Tutumları Arasındaki Farklılıkların İncelenmesi. 2012. 
21. Kürtüncü Tanır M, Kuğuoğlu S. Pediatrik Yaşam Kalitesi Envanteri (PedsQL) Sağlık Bakım Memnuniyeti Hematoloji/ Onkoloji Modülü Ebeveyn Formu Geçerlik Güvenirliliği. Ankara Sağlık Hizmetleri Derg. 2012;11(2). https://doi.org/10.1501/ Ashd_0000000079

22. Avis M, Reardon R. Understanding The Views Of Parents of Children With Special Needs About The Nursing Care Their Child Receives When In Hospital: A Qualitative Study. J Child Heal Care. 2008 Mar 1;12(1):7-17. https://doi. org/10.1177/1367493507085615

23. Milutinović D, Simin D, Brkić N, Brkić S. The Patient Satisfaction With Nursing Care Quality: The Psychometric Study of The Serbian Version Of PSNCQ Questionnaire. Scand J Caring Sci. 2012 Sep 1;26(3):598-606. https://doi.org/10.1111/j.14716712.2012.00969.x

24. Aktaş E, Teksöz E, Ocokçı AF. Ailede Kadınının Değișen Rolünün Çocuk Sağlığına Etkisi Ve Aile Merkezli Bakımın Önemi. Vol. 28, Ege Üniversitesi Hemşirelik Fakültesi Dergisi. 2012 Jan.
25. Broger B, Zeni MB. Fathers' Coping Mechanisms Related to Parenting a Chronically III Child: Implications for Advanced Practice Nurses. J Pediatr Heal Care. 2011 Mar 1;25(2):96-104. https://doi.org/10.1016/j.pedhc.2009.09.004

26. Stenberg U, Ruland C, Miaskowski C. Review Of The Literature On The Effects Of Caring For A Patient With Cancer. Vol. 19, Psycho-Oncology. John Wiley \& Sons, Ltd; 2010. p. 1013-25. https://doi.org/10.1002/pon.1670

27. Illhan MN, Toygar ȘA. Bir Üniversite Hastanesinde Ayaktan Tedavi Gören Hasta Ve Yakınlarının Memnuniyet Durumlarının Değerlendirilmesi. Uluslararası Sağlık Yönetimi ve Strat Araștırma Derg. 2017;3(1).

28. Reyhani T, Aemmi S, Emami Zeydi A. The Effect Of Teacher's Presence At Children's Bedside On The Anxiety Of Mothers With Hospitalized Children: A Randomized Clinical Trial. Iran J Nurs Midwifery Res. 2016;21(4):436. https://doi.org/10.4103/17359066.185610 